\title{
Fishing Community Wireless Network Concept in Kuala Rompin, Pahang, Malaysia
}

\author{
W. Hashim, A.F. Ismail, H. Mohd Radzi, F. H. Mohamed Salleh, Z. Ismail, Z. Mohamad
}

\begin{abstract}
Fisheries communities are the main suppliers of Malaysian local maritime resources. These minority groups are synonym with low income, low education level, and plagued with myriad of economic limitations. The article outlines a network infrastructure concept that deemed suited for fishing communities; designed based on surveys' outcomes conducted on a group of fishermen in Kuala Rompin, Pahang, Malaysia. The survey outcomes were analysed using induction method. System requirements are tabulated and the design of such concept is explained. The main motivation of the studies is that such community to own their network that can facilitate the establishment of community resilience. The ideas where available resources are exploited in hope to improve the community's living standard especially their household incomes. The fundamental concept of the system is directed towards three main elements; namely available technologies, community empowerment and cost-efficiency.
\end{abstract}

Keywords: Community network, fishery, communication system, wireless radio, long-range network.

\section{INTRODUCTION}

The general principle of alleviating poverty by facilitating self-sufficiency has a long history. A piece of proverbial wisdom once stated, 'Give a man a fish, and you feed him for a day. Teach a man to fish, and he will feed himself for a lifetime'. Rather than teaching a man to fish, there is a dire need to empower fishing communities in managing their scarce resources, encourage sustainably and hence promote community resilience. Community resilience by definition is the sustained ability to utilize available resources to respond to adverse situations [1]. The said level demands for smart development, improved ecosystem, and adaptation strategies. Based on preliminary research findings on community project titled; 'Demystifying Digital Requirement for Fishing

Communities' [2], several commonalities on issues previously identified within the United Nation's Food and Agriculture Organization (FAO) studies [3] on similar subjects were encountered. Among the challenges that potentially lead towards poverty, based on profiling of local fishing communities can be categorized into five domains as shown in Figure 1.
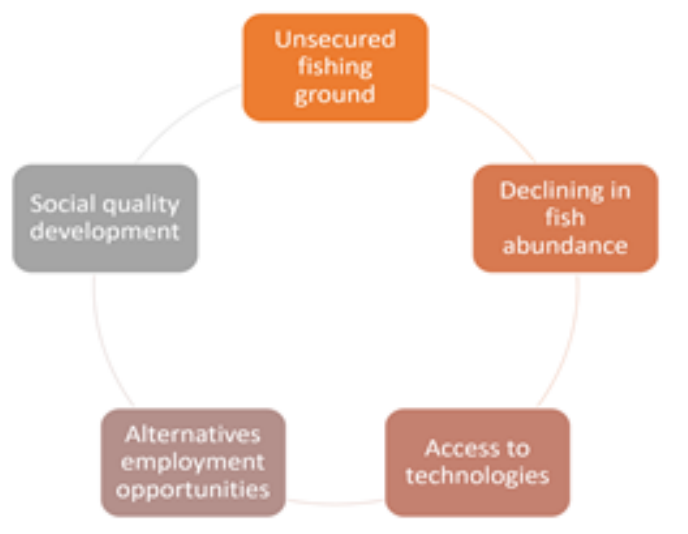

Figure 1. Five aspects of challenges in Kuala Rompin fishing communities

These issues remain unsolved globally. Research on how to empower these communities to keep them sustainable is ongoing. This is especially true when Internet is at their fingertips. The collaboration was established with the Kuala Rompin Fishing Association to understand the issues in detailed, for the community network infrastructure concept to be best designed.

\section{CHALLENGES ENCOUNTERED BY FISHING COMMUNITIES}

The following sub-sections further describe each of the challenges; in more details, as the result of the survey.

\section{A. Insecure fishing ground}

The presences of illegal foreign fishing boats on the shore of Kuala Rompin waters are causing concerns to the local fishermen. These intrusions not only resulted in financial losses to the fishermen due to declining fish catch but they are also damaging the ecosystem. The illegal trawler boats operators are violating Zone A provisional areas and threatening the inshore fishermen, who typically operate in areas less than 5 nautical miles $(10 \mathrm{~km})$ from the shore.
Revised Version Manuscript Received on August 19, 2019.

W. Hashim, Institute of Informatics and Computing in Energy, Universiti Tenaga Nasional, Malaysia (email: Wahidah@uniten.edu.my)

A.F. Ismail, Faculty of Engineering, International Islamic University Malaysia, (email: af_ismail@iium.edu.my)

H. Mohd Radzi, Institute of Informatics and Computing in Energy, Universiti Tenaga Nasional, Malaysia. (email: husni@uniten.edu.my)

F. H. Mohamed Salleh, Institute of Informatics and Computing in Energy, Universiti Tenaga Nasional, Malaysia (email: faridahh@uniten.edu.my)

Z. Ismail, Institute of Informatics and Computing in Energy, Universiti Tenaga Nasional, Malaysia.(email: zurina@uniten.edu.my)

Z. Mohamad, Universiti Malaysia Terengganu, Malaysia.(email: zaleha.m@umt.edu.my) 
Despite the banning of trawl net since 2016; except for Zone $\mathrm{C}$ [4], the trawler boats came at midnight time, moving in silence, in the pitch of darkness where they went undetected. This has led to the mass killing of small-sized fishes where they become off-value entities except for making crop fertilizer.

\section{B. The decline of fish abundance}

The decline of fish abundance is another issue threatening the livelihood of the fishermen. When it is overfished, fewer fishes are available for the inshore fishermen. It is now happening in Senegal. Due to uncontrolled fishing activities, the shore is almost empty [5]. In recent survey conducted in Kuala Rompin, the decline was due to the violation of fishing fleets operating within restricted or prohibited areas. Although there is a dedicated authority to prevent such from happening, the pervasive illegal fishing is unstoppable and unbearable. Overfishing can certainly cause negative impact to the entire ecosystems. It can change the size of remaining fishes, as well as how they reproduce and the speed at which they mature. Figure 2 shows the distribution of fishing concentrations in South East Asia. The suggestion from Kuala Rompin fishermen is such that artificial reefs areas can be created from detained illegal boats which evidently can also prevent trawler boats from entering the prohibited areas. Artificial reefs from sunken vessel have been described in [6] where the article highlights the advantages and practices at Bukit Maung, Penang in late 2018 [7].

\section{C.Access to technologies}

Inshore fishing for Zone $\mathrm{A}$ is defined as activities within 5 nautical miles $(10 \mathrm{~km})$ from the shoreline of Malaysia. Currently due to lack of gears and equipment, the inshore fishermen are facing difficulties to communicate reliably with the other fishermen, family or the coastal community. Existing Mobile Network Operator (MNO) provides service via telecommunication base station tower built at shoreline that offers coverage to the nearby community. The coverage is dedicated and typically focused for population coverage instead of area coverage. The issue is that it had been observed where the fishermen community are in general sporadically distributed. The populations are diverse and scattered around in the area, which is can to some certain extent be considered as highly rural area. Off the coast, shore areas are not required to be covered by mobile network coverage. Therefore, in such instance, the fishermen are not likely able to communicate all the time reliably. Most of the time, the fishermen have to rely on their gut feelings and experience in identifying their current location. Another primary concern is when the fishermen encounter dangerous circumstances, which requires them to provide exact location info of their whereabouts, and yet they are unable to make known of their position. Critical issues that need urgent attention are public concerns, where illegal fishermen or pirates encroach into the Zone A water territories since most areas experiencing depleted fisheries and the local fishermen are not able to communicate with the authority to seek help or report of the incident.

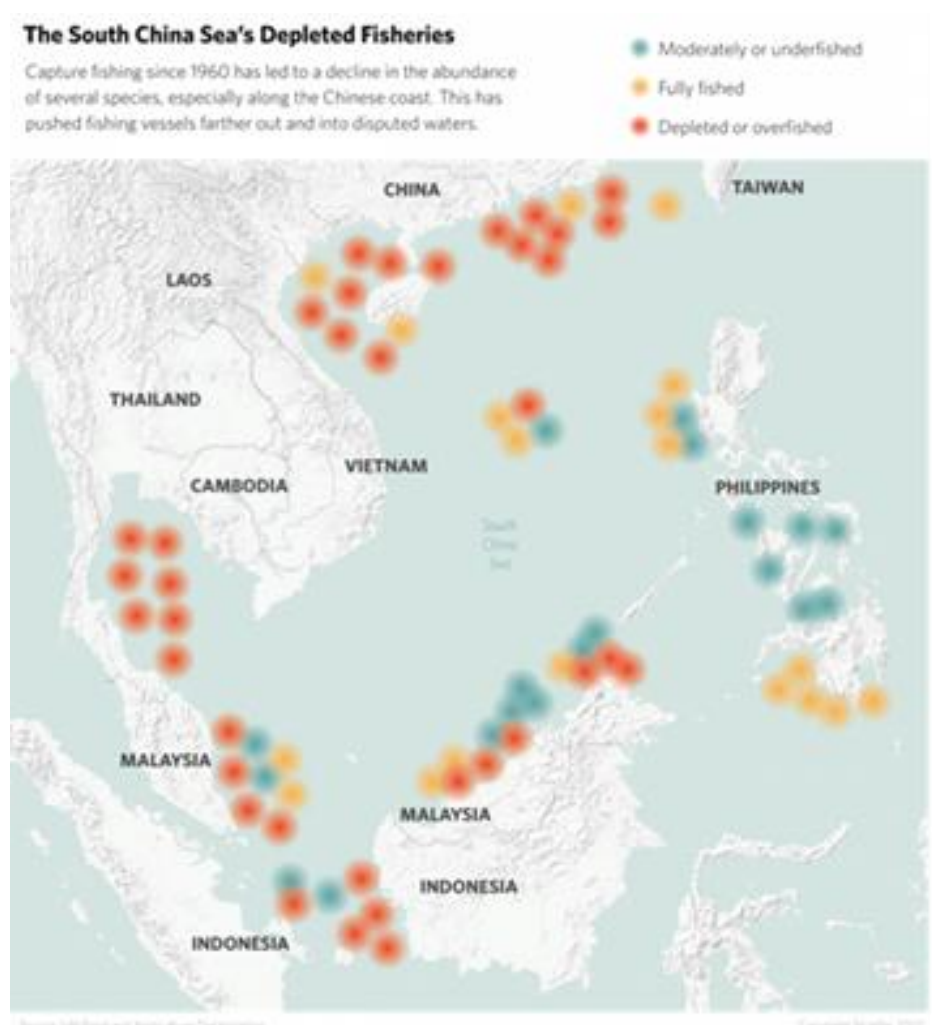

Figure 2. Distribution of fishing areas based on their concentrations in South East Asia

\section{D.Alternative employment opportunities}

In a year, the duration for Kuala Rompin fishermen can go fishing is only 8 months, i.e. March to October. The fishermen typically have to stay-put indoor during the other 4 months, November to February due to rough sea and weather conditions [8]. Within this period, the fishermen will have to keep themselves engage in odd jobs to support their living. Sadly, alternative employment opportunities are too few within the district. Miserable land tenure is also a problem; where many fishermen do not have the rights to the property where they live, let alone to embark on plantation such as pineapple at their backyard as suggested by minister early last year [9]. In Kuala Rompin, women account for most of the workers in secondary marine-related activities such as fish processing and marketing [9]. However, if the supply of fish is somehow limited, the employments dropped, and such activities experienced reduced productive.

\section{E. Social quality development}

Stronger and more aggressive efforts in dealing with education, income, and health issues in fishing communities would undoubtedly help to mitigate poverty and social problems. The bonus benefit includes the training, which will make it easier for the community to be independent and solve their fishery-related challenges on their own. Kumpulan Nelayan Wanita (KUNITA) or Women Fishing Group is a particular association established under the supervision of the Fisheries Development Authority of Malaysia (LKIM) with the objectives of empowering the women of fishing communities. KUNITA function as a center for women in the 
community to outreach and upgrade their current living status through various economic activities both traditional and commercial. KUNITA has made much progress and achieved much success throughout its establishment. The need to empower become more urgent as it will not only empower the moment individually, but it is hoped by improving the women, it will create a ripple effect of transforming the whole community through the next generation.

Having discussed the above challenges, the next section describes the application of system logic in concluding the need for community network system for resolving associated issues. System logic is chosen due to its concern with making inferences from observed phenomena, in contrast to intuitive truths [9].

\section{SYSTEM LOGIC INDUCTIVE METHOD\& RESULTS}

Induction as according to [10] is the process by which one can conclude that what is true of specific individuals of a class, or is true of the whole class, or that what is right at certain times will be valid under similar circumstances at all times. A similar concept has been applied in the studies by making inferences into two categories of $\mathrm{X}$ and $\mathrm{Y}$. The theorem of induction has been adopted into the derivation of the framework. The theorem is illustrated in Figure 3 [10].

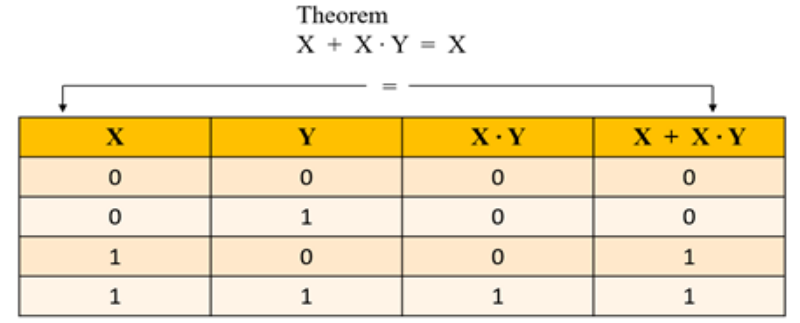

Figure 3. Proving of a theorem by perfect induction

The theorem is then applied by representing variable $\mathrm{X}$ and $\mathrm{Y}$ with the induction logic statement and condition shown in Table 1. Based on Table 1, the survey conducted upon the fishing community involving samples with ten interviewees deduced the scoring for such logic according to agreement or statement to support those inferences. This was thoroughly analyzed using NVIVO qualitative analysis software based on several recorded videos during the interview sessions. The research finding categories are organized in Figure 4.

Table 1. Description of $\mathrm{X}$ and $\mathrm{Y}$ inferences and logic statement

\begin{tabular}{|c|l|c|c|}
\hline e Variabl & $\begin{array}{l}\text { Inference } \\
\text { description }\end{array}$ & Require & $\begin{array}{c}\text { Not } \\
\text { required }\end{array}$ \\
\hline $\mathrm{X}$ & $\begin{array}{c}\text { Community } \\
\text { network system }\end{array}$ & \multirow{2}{|c|}{1} & 0 \\
\hline $\mathrm{Y}$ & $\begin{array}{c}\text { Internet } \\
\text { connectivity }\end{array}$ & \\
\hline
\end{tabular}

To decide Boolean 0 or 1 for the logic inferences associated with issues elaborated in section 2, a simple scoring matrix as shown in Table 2 had been used. The induction theorem shows that 4 out of 5 elements are concluded to the need for community network system.

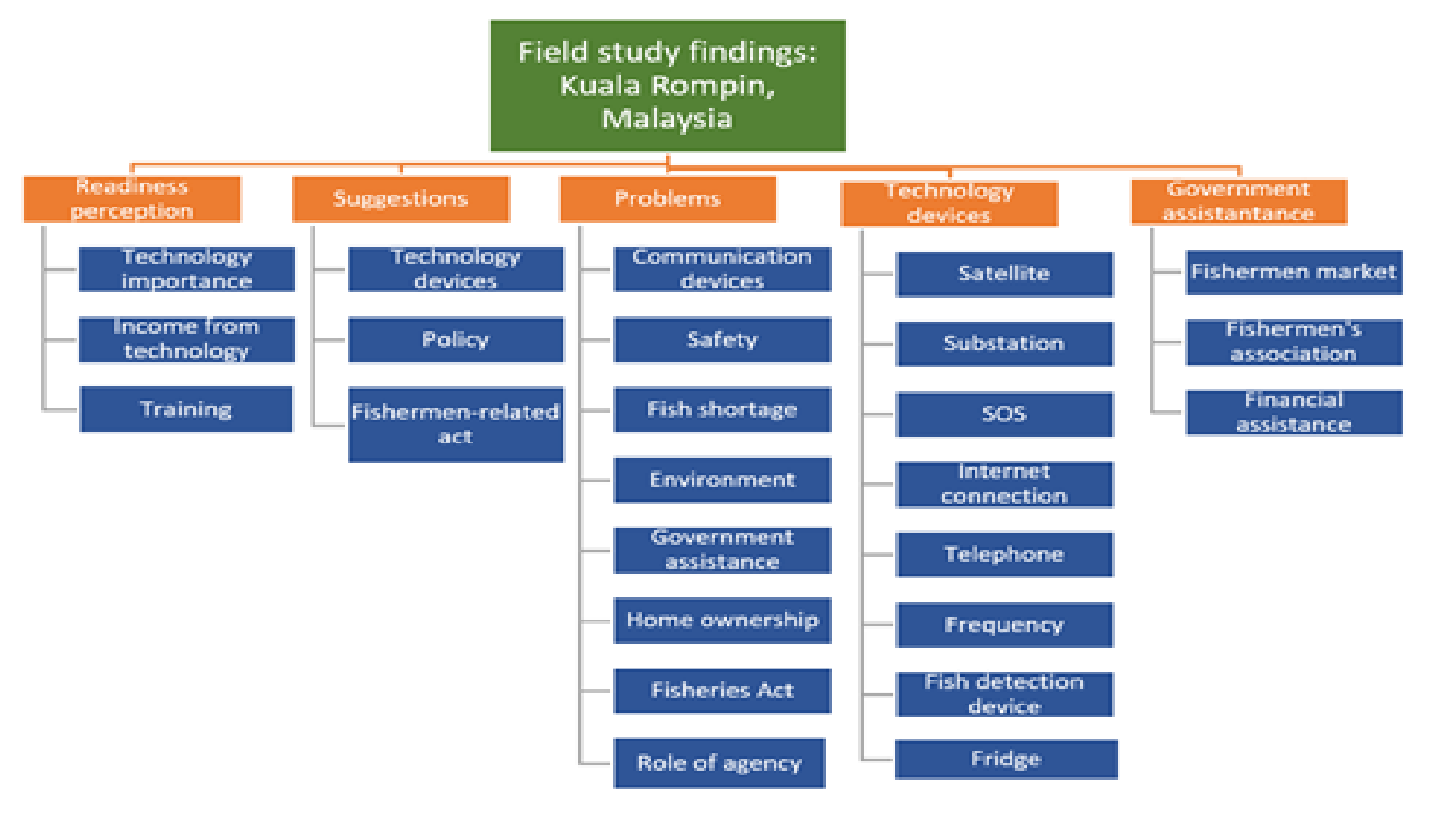

Figure 4. Organization of research findings from Kuala Rompin survey 
Table 2. Scoring on the inferences

\begin{tabular}{|c|l|c|c|l|l|}
\hline No & Challenges & $\begin{array}{l}\text { X-Community } \\
\text { communication } \\
\text { system }\end{array}$ & $\begin{array}{l}\text { Y - Internet } \\
\text { connectivity }\end{array}$ & $\begin{array}{l}\text { Evidence from the } \\
\text { survey }\end{array}$ & $\begin{array}{l}\text { Conclusion } \\
\text { on X }\end{array}$ \\
\hline A & $\begin{array}{l}\text { Insecure } \\
\text { fishing } \\
\text { ground }\end{array}$ & 1 & 0 & $\begin{array}{l}\text { Safety issue when } \\
\text { going fishing whereno } \\
\text { communication signals } \\
\text { miles away. }\end{array}$ & Require \\
\hline B & $\begin{array}{l}\text { Decline of } \\
\text { fish } \\
\text { abundance }\end{array}$ & 1 & 0 & $\begin{array}{l}\text { Need communication } \\
\text { device to report } \\
\text { intrusion into } \\
\text { inappropriate fishing } \\
\text { zone. }\end{array}$ & Require \\
\hline C & $\begin{array}{l}\text { Access to } \\
\text { technologies }\end{array}$ & 1 & 1 & $\begin{array}{l}\text { Need an affordable } \\
\text { device that can detect } \\
\text { the areas with high } \\
\text { fish concentration } \\
\text { with minimum 2km } \\
\text { detection range. }\end{array}$ & Require \\
\hline D & $\begin{array}{l}\text { Alternative } \\
\text { employment } \\
\text { opportunity }\end{array}$ & 0 & 1 & $\begin{array}{l}\text { Production of fish } \\
\text { byproducts requires } \\
\text { marketing and } \\
\text { knowledge }\end{array}$ & Not required \\
\hline E & $\begin{array}{l}\text { Social } \\
\text { quality } \\
\text { development }\end{array}$ & 1 & 1 & $\begin{array}{l}\text { Affordable tuitions } \\
\text { for the children to } \\
\text { mprove their studies } \\
\text { and device } \\
\text { technology trainings } \\
\text { for fishermen to keep } \\
\text { them knowledgeable. }\end{array}$ & Require \\
\hline
\end{tabular}

\section{PROPOSED FRAMEWORK}

Regarding the induction analysis in section 3, a framework as illustrated in Figure 5 is proposed. The main objective of developing the framework of a fishing community wireless network is to elucidate the Malaysian national food security issue. The outline of the framework will have its core based on the findings of conducted surveys. At this juncture, a
Long-Range WIFI (LRWIFI) system managed by Malaysia Fishery department is proposed as the potential solution to disentangle the inshore fishermen's predicaments. The proposed LRWIFI can be customized to cater to the needs of all fishermen when they are out at sea. It is envisioned that such wireless network connectivity can be utilized as among others; 1. Monitoring Tool; 2. Public Safety System; 3. Emergency Panic Kit; 4. Two-way Communication System.

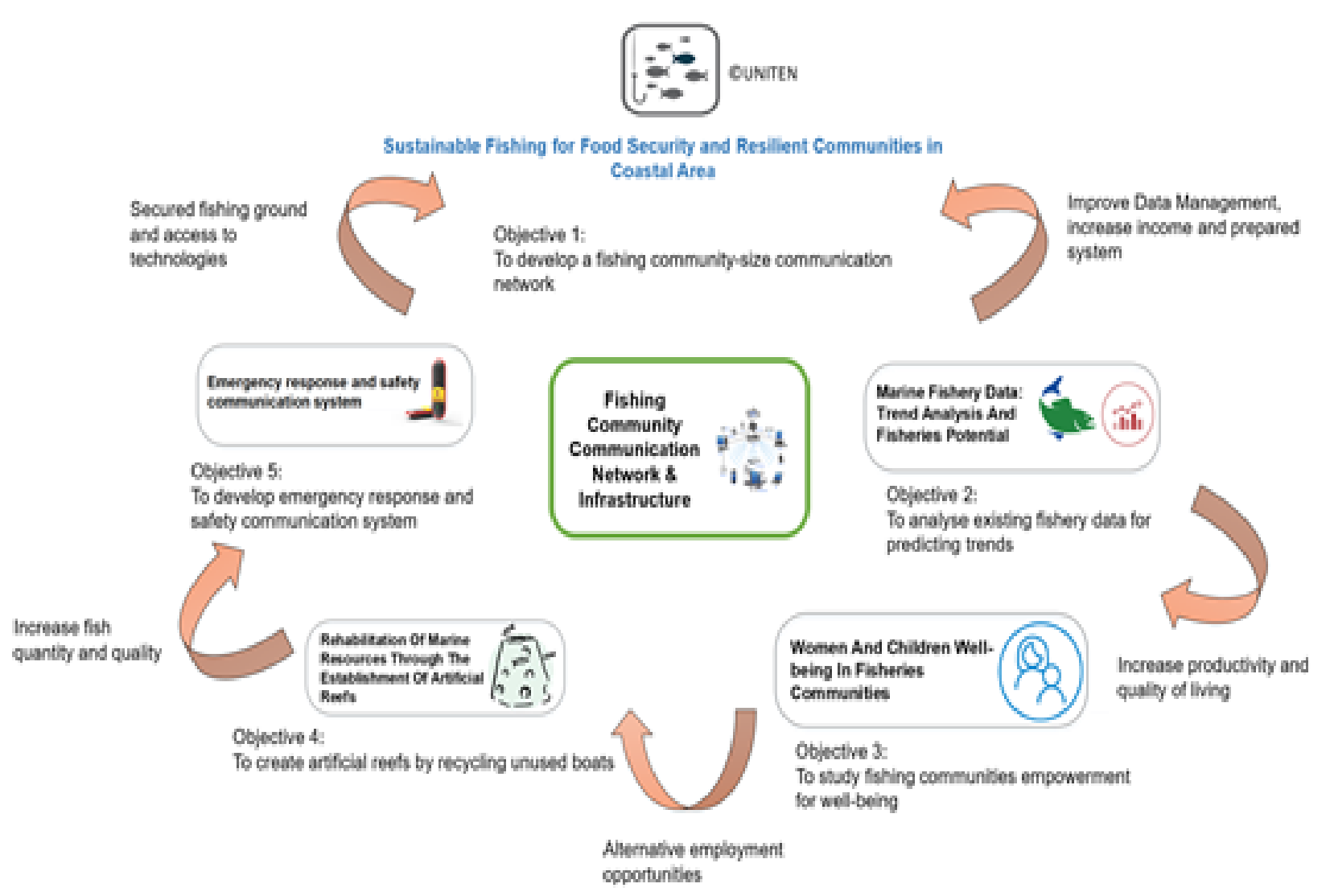

Figure 5. Proposed framework based on Kuala Rompin survey 
The rationale of a Long-Range WIFI system is because it will involve the lowest cost of implementation. There will be considerable investment in the development of the monitoring for sure, but this can be counterpoised by lower cost of acquisition of the commercial-of-the-shelf User Equipment (UE). It will be certainly more accessible and affordable for every fisherman to use ones existing COTS mobile devices (handphone) with downloadable customized software or app installed rather than investing in a custom-made UE based on complicated long-range (LoRa) and $5 \mathrm{G}$ radio connection. This will facilitate ease of deployment and acquirement of the relevant UE, wherewith such initiative, this will not only improve the safety of the fishermen but hopefully one day it will also improve their productivity level.

A proof of concept monitoring station can be set up onshore, where location information signal from the fishermen UE can be programmed to periodically send out signals so that their location and safety can always be monitored. Apart from a dedicated monitoring function, the envisioned LRWIFI link also enables two-way or even group communication between onshore and inshore contacts. The system will, therefore, enable effective communication between the fishermen and monitoring station, and also among other fishermen in providing critical updates and warnings about impending weather changes or other crucial information, that was not able to be conveyed previously.

At the initial stage, 3 towers can be positioned at $10 \mathrm{~km}$ apart along the shoreline as per depicted in Figure 6. The towers with a height of around $10 \mathrm{~m}$ should be capable of offering service coverage within radius of $13 \mathrm{~km}$ [11]. The configuration of such proof of concept offers area coverage possibly up to $500 \mathrm{~km} 2$. The POC with minimum 3 user equipment can be deployed to test the onshore and inshore communication service quality. One tower can house the Long Range WIFI Base station while the remaining two can be installed with repeaters to extend the coverage area. The native home-grown app can be developed and later on installed in the COTS mobile units that have pre-requisite components namely a WIFI transceiver and a Global Navigation Satellite System (GNSS) module.

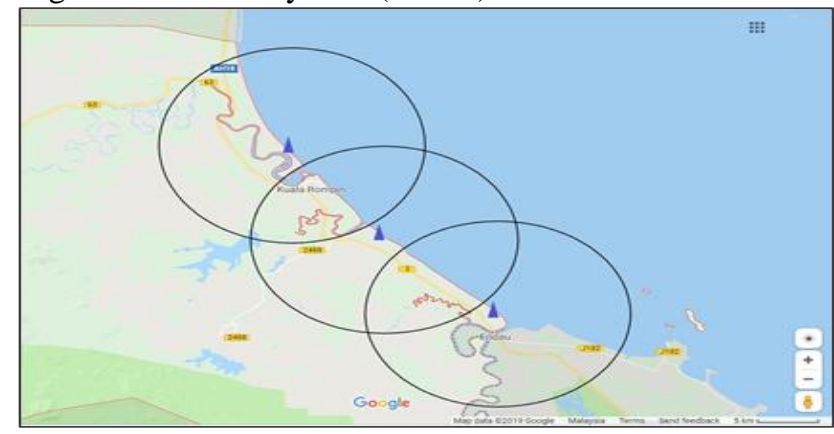

Figure 6. Possible placement of the LRWIFI towers

The WIFI transceiver is a requirement since the communication link establishment is based on LRWIFI protocol. The GNSS module, which can be the U.S. made Global Positioning System (GPS) will be able to compute the exact location of the fishermen. In the set-up, inbuild cellular transceivers can act as the backup for the communication link when preventive maintenance or corrective maintenance work is required on the LRWIFI system.

Concurrent to such core infrastructure and communication network development, data collection on existing fish information can also be conducted. The collection at the initial stage may involve intensive data entry as per previously reported that some of the data are still kept in hardcopy forms rather than in digital format, a local server housing the system database in can be installed at the Rompin Fishing Association facility. The prototype system can be developed assembled at the research laboratory and once the data is ready for migration to local server, an advanced setup of private cloud storage will be developed accordingly. It is also anticipated that data analyses scope will include sensory data collection as well as data integrity monitoring.

It is envisioned that while system development is taking place, another group of investigators can carry out the social studies research. The researchers are expected to investigate the existing issues faced by the women and children of Kuala Rompin fishing community. The proposed framework will also be focusing on the best practice of managing the artificial reefs by possibly recycling abandoned boats or the parts. It is expected that the method does not only introduce a lower cost but also a better option for the environment. The Practical Guidelines for Artificial Reefs in the Mediterranean and the Black Sea from the United Nation's Food and Agriculture Organization FAO will then be referred [12]. The detained boats can be supplied by LKIM which they are more than ready to dispose or get rid-off. The process to dump these boats can be taken care by the experts in Marine studies. Methodologies to assess effectiveness and impacts of artificial reefs and standardized monitoring procedures also need to be further researched, in hope, such procedure can turn into new employment opportunities, especially when it involves combination of new communication network infrastructure. Sensors installed in array positioned can be one of the possibilities as part of the future Internet of Things (IoT) implementation [13]. Artificial reefs may also require some degree of management either to assure that they provide the desired outcomes for both biological resources and users. Additionally, effective management can help reduce potential risks such as damage to fishing gears, injuries to recreational divers visiting the reef, decomposed materials or movement of the reef units off-site.

\section{CONCLUSION}

A survey on the challenges faced by the fishing community in Kuala Rompin, Pahang, Malaysia had been conducted. The survey data were analysed using theorem of induction which resulted in the requirement list for a fishing community wireless network. The framework for the network is formed based on assessment on the issues as well as from the received responses. Each component in the framework is outlined and the design, as well as the implementation planning of such a wireless network, are discussed. The hardware setup for such wireless network and the practicality associated with it will be presented in upcoming publications. 


\section{ACKNOWLEDGEMENTS}

This research was supported by Uniten Chancellery Foundation (YCU) Project code 201801001YCU/01 and IIUM's Collaborative Research Initiative Grant Scheme (C-RIGS). Heartfelt thanks to funders and Kuala Rompin Fishing Association for providing the financial support and cooperation. Also, special thanks to Mr. Alan from FILPAL Sdn Bhd for his advice and ideas in wireless network planning.

\section{REFERENCES}

1. D. Lerch, Editor, Community Resilience Reader: Essential Resources for an Era of Upheaval, Island Press, Washington (2017)

2. W. Hashim, H. Mohd Radzi, F. H. Mohamed Salleh and Z. Ismail, J. Fishing communities and requirements for digital technologies: A case study, UNITEN internal report, unpublished (2019)

3. Factsheet people and ocean, The Ocean Conference, United Nation New York, June (2017)

4. Ban on trawl net fishing from 2016, StarOnline November (2014)

5. Overfished: In Senegal, empty nets lead to hunger and violence, May (2018)

6. A. Ali and V.T. Sulit, Big Artificial Reefs for Improved Enhancement of Fishery Resources: Experience of Malaysia, Fish for the People (2014)

7. In Malay language, Jabatan Perikanan labuh 19 unit tukun tiruan, halang pencerobohan nelayan pukat tunda, Bulletin Mutiara, Sept (2018)

8. J. S. Mill, A System of Logic, Ratiocinative and Inductive: Being a Connected View of the Principles of Evidence, Methods of Scientific Investigation, Reprint from 1858 book by Forgotten Books February 10 (2017)

9. P.H. Kok, M.F. Mohd Akhir, F. Tangang, M.L. Husain, Spatiotemporal trends in the southwest monsoon wind-driven upwelling in the southwestern part of the South China Sea, Methods of Scientific Investigation, PLOS ONE (2017)

10. P. K. Sinha and P. Sinha, Chapter 06 Boolean Algebra and Logic Circuits, Computer Fundamentals lecture slides, (2014)

11. A.T. Adediji, S.O. Adebusola and J.S. Ojo, Estimation of Radio Horizon Distance Using Measured Meteorological Parameters over Some Selected Locations in Nigeria, Asian Journal of Physical and Chemical Sciences (2019)

12. J. Ramos, P.G. Lino, A. Himes-Cornell, M.N. Santos, Local fishermen's perceptions of the usefulness of artificial reef ecosystem services in Portugal, PeerJ Life \& Environment (2019)

13. M.I. Dzulqornain, M.U. Harun Al Rasyid, and S. Sukaridhoto, Design and Development of Smart Aquaculture System Based on IFTTT Model and Cloud Integration, MATEC Web of Conferences (2018)..

\section{AUTHORS}

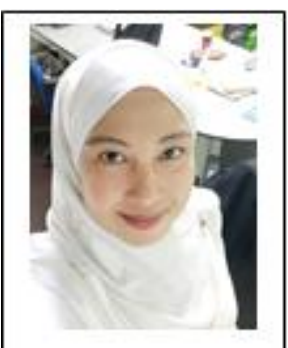

\section{Wahidah Hashim}

Wahidah Hashim received the bachelor's degree in information technology, business management and language from the University of York, U.K., the M.Sc. degree in multimedia technology from the University of Bath, U.K., and the Ph.D. degree in telecommunication engineering from King's College London, U.K. She has been with the Institute of Informatics and Computing in Energy (IICE), Universiti Tenaga Nasional, as an Associate Professor, since 2016. Wahidah is a trainer at International Malaysia Training Centre.

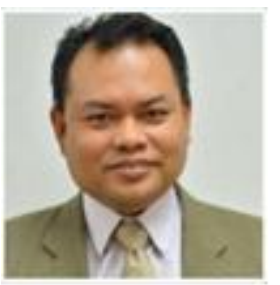

\section{Ahmad Fadzil Ismail}

Ahmad is currently a lecturer at the Department of Electrical and Computer Engineering, Faculty of Engineering, International Islamic University Malaysia (IIUM). He completed his bachelor degree studies in Electrical Engineering at Gannon University, Pennsylvania, USA with Cum Laude Latin honors. He holds MSc and Ph.D. from University of Essex, University of Bath, UK, respectively. He is registered with Board of Engineering Malaysia as a Professional Engineer and also a senior member of IEEE. His research interests include development of active and passive target tracking algorithms, satellite communications, wireless systems and microwave and millimeter-wave technology

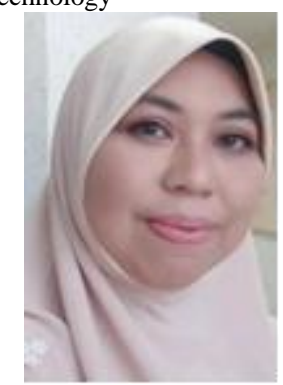

\section{Husni Mohd Radzi}

A graduate of IIUM, she obtained her first degree from of Kulliyah of Human Sciences majoring in Psychology in 2001. She pursued her study in guidance and counseling from UPM Faculty of Education and completed her master in the same field in 2011. She is currently a Ph.D. candidate in USIM Faculty of Leadership and Management majoring in Guidance and Counselling. She joined UNITEN since 2007 till date where she teaches, counsel and provide training for both student and staff in house and outside of campus. She is a registered and licensed counselor certified by Board of Counsellor Malaysia (KB02159) (PA01608), Certifies HRDF Trainers (TTT/7057) and NLP Certified Member 0115-311322 (International)

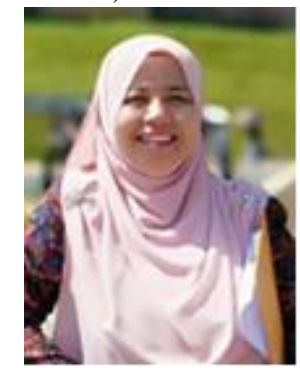

Faridah Hani Mohamed Salleh

Ts. Dr. Faridah Hani has just completed her Ph.D. in Computer Science in the year 2019. Most of her research work involving data analytics techniques, with application to biology-related data. In her research, she proposed the best method to analyse data with the following characteristics; stochastic non-linear, multidimensional, and data affected mainly by multicollinearity. She tested several regression-based methods, machine learning and statistical-based methods in her works.

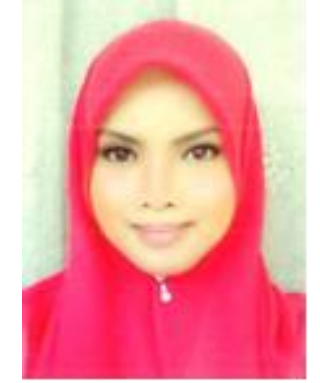

\section{Zurina Ismail}

Zurina is currently a researcher at the Institute of Energy and Research (IEPRe) UNITEN and lecturer at College of Business Management and Accounting (COBA), UNITEN. She holds a Master Business Administration from UNITEN, and Bachelor Degree in Mass Communication (Hons) USM. Most of her research are reflections of social economic impact studies. Her most recent on-going research project is the Prepaid Meter Implementation and its Potential Economic Impact to Malaysia Electricity Industry funded by the Energy Commission.

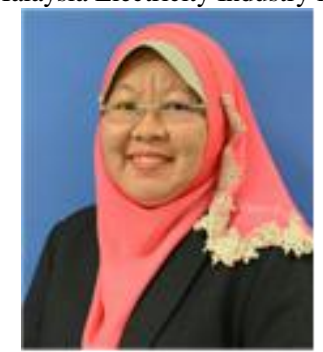

\section{Zaleha Mohamad}

Dr Zaleha Mohamad holds a Bachelor of Business Administration (Hons) from Universiti Utara Malaysia, a Master's Degree in Business Administration (Entrepreneurship) from Universiti Teknologi Malaysia and obtained her Ph.D in Management (Entrepreneurship in Tourism) from Universiti Malaysia Terengganu. Her research interest includes Digital entrepreneurship, entrepreneurship in tourism, tourism management, entrepreneurship, small and medium enterprises, management, human resource, and marketing. She has published her works in several international journals and actively involved in various research grants

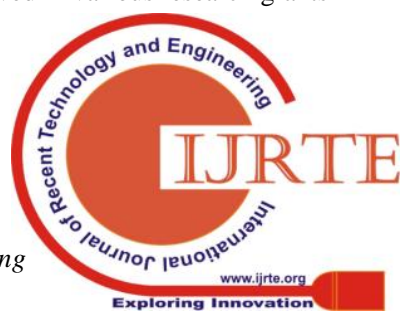

